\title{
Optimization of Bacteria Amylase Activity from Bacillus licheniformis Strain SEM11
}

\author{
Ruth Rize Paas Megahati ${ }^{*}$, Mansyurdin², Anthoni Agustien² and Djong Hon Tjong ${ }^{2}$ \\ ${ }^{1}$ Biology Education Department STKIP PGRI Sumbar, Padang, West Sumatera, Indonesia \\ ${ }^{2}$ Biology Department, Faculty of Mathematics and Natural sciences, Andalas University, Padang, \\ West Sumatera, Indonesia \\ *Corresponding author
}

\section{A B S T R A C T}

\section{Keywords}

Bacteria amylase, Optimum condition, Optimization, Amylase activity, Bacillus licheniformis strain SEM11.

\section{Article Info}

Accepted: 24 September 2017 Available Online: 10 November 2017
Amylase produced by bacteria or bacteria amylase is an enzyme that can hydrolyze starch to sugar. Bacteria amylase is successfully replaced chemical hydrolysis in starch processing industries. Bacteria amylases are commercially important selectively hydrolyze the $\alpha-1,4$ sugar linkage in polysaccharides. Bacteria amylase is used commercially in many industries such as textile, pharmaceutical, food, glucose syrup, and detergent additive. Bacteria amylases are traded as much as $25 \%$ of the total another enzyme. Bacteria amylase from thermo-alkaliphile bacteria more attractive to use in industry because it is resistant to high temperature and $\mathrm{pH}$. Bacillus licheniformis strain SEM11 is an amylaseproducing bacteria that has been isolated from Semurup hot spring. Semurup hot spring, Kerinci district, Jambi province, Indonesia has the temperature $80^{\circ} \mathrm{C}$ dan $\mathrm{pH} 8.4$. Bacteria amylase activity of Bacillus licheniformis strain SEM11 still low is $68,52 \mathrm{U} / \mathrm{ml}$ because it's wild-type bacteria. The purpose of this study was to increase bacteria amylase activity of Bacillus licheniformis strain SEM11 through optimization of bacteria amylase activity. The results showed that bacteria amylase activity increased by using $1.5 \%$ rice substrate, at temperature $55^{\circ} \mathrm{C}, \mathrm{pH} 8.0$, fructose as the carbon source, and soybean as a source of nitrogen. Bacteria amylase from thermo-alkaliphilic Bacillus licheniformis strain SEM11 potentially in various industries because it has a high bacteria amylase activity.

\section{Introduction}

Bacteria is one of the microbes producing various enzymes, such as protease, lipase, xylanase, and amylase. Amylase produced by bacteria or bacteria amylase is an enzyme that can hydrolyze starch to sugar. Bacteria amylase is successfully replaced chemical hydrolysis in starch processing industries. Bacteria amylases are commercially important selectively hydrolyze the $\alpha-1,4$ sugar linkage in polysaccharides. Amylase hydrolyzes polysaccharide such as starch, glycogen into simple sugar constituents (Babu et al., 2014). Bacteria amylase is used commercially in many industries such as textile, pharmaceutical, food, glucose syrup, and detergent additive. Amylases are traded as much as $25 \%$ of the total another enzyme (Souza and Magalhaes, 2010).

Bacteria amylase from thermo-alkaliphilic bacteria is more attractive for industries use because it is resistant to high temperature and 
$\mathrm{pH}$. One of the hot springs in Indonesia which has high temperature and $\mathrm{pH}$ is Semurup hot spring, Kerinci district, Jambi province, Indonesia, ie $80^{\circ} \mathrm{C}$ and $\mathrm{pH} 8.4$ or almost similar to hot spring in Zimbabwe Africa with pH 9.3 (Remigio et al., 2012). Bacillus licheniformis strain SEM11 has been successfully isolated from Semurup hot spring. Bacteria amylase activity of Bacillus licheniformis strain SEM11 still low is 68,52 $\mathrm{U} / \mathrm{ml}$ because it's wild-type bacterial. Therefore it is necessary to increase bacteria amylase activity through optimization of bacteria amylase activity and production medium, such as optimization of substrates, substrates concentration, inoculum concentration, agitation speed, and nutritional factors, especially carbon and nitrogen sources. Bacteria amylases have a broad application in industries due to their stability, high enzyme activity at various parameters and cost-effective production (Khusro et al., 2017). The production of enzymes by microorganisms as well as the enzyme yield depends on the nutritional factors especially carbon and nitrogen sources (Kumar et al., 2012). The purpose of this study was to increase bacteria amylase activity of Bacillus licheniformis strain SEM11 through optimization of bacteria amylase activity and production medium. Amylase which could be a potential in various industries because it has a high bacteria amylase activity.

\section{Materials and Methods}

\section{The sample collection}

The sample of Bacillus licheniformis strain SEM11 was collected from Semurup hot spring located in Kerinci district, Jambi province, Indonesia.

\section{Chemicals}

$\mathrm{Na}_{2} \mathrm{CO}_{3}$, KNA tartarat, $\mathrm{NaHCO}_{3}, \mathrm{Na}_{2} \mathrm{SO}_{4}$, $\mathrm{CuSO}_{4.5} \mathrm{H}_{2} \mathrm{O}, \mathrm{H}_{2} \mathrm{SO}_{4}$, amonium molibdat, disodium arsenat, $\mathrm{KNO}_{3}, \mathrm{NaNO}_{3}$, fructose, sucrose, lactose, and glucose.

\section{Media and Buffers}

Basal media, buffer potassium phosphate $(\mathrm{pH}$ 6.5-8.5).

\section{Substrates}

Various substrates were used to determine bacteria amylase optimum activity such as rice, wheat, sago, and potato. Bacteria amylase activities using various substrates were assayed by using Samogy-Nelson method (Nelson, 1944).

\section{Substrates concentrations}

Bacteria amylase activity with various substrates showed that rice had the highest activity. Bacteria amylase activities of rice substrate was tested at various concentrations, i.e: $0.5,1.0,1.5$ and $2.0 \%(\mathrm{w} / \mathrm{v})$.

\section{Temperature}

The optimum temperature for amylase activities was determined by incubating amylase at different temperature $\left(45-60^{\circ} \mathrm{C}\right)$ using the substrate with $1.5 \%$ concentration and amylase activities were tested.

\section{pH}

Amylase activities of the substrate were tested at concentration $1.5 \%$ in buffer potassium phosphate ( $\mathrm{pH}$ 6.5-8.5).

\section{Carbon and nitrogen sources}

The nutritional factors especially carbon and nitrogen sources were adding into basal medium $1.5 \%$ carbon sources (fructose, sucrose, lactose, and glucose) and $1 \%$ nitrogen sources (soybean flour and urea), and $0.2 \%\left(\mathrm{KNO}_{3}\right.$, and $\left.\mathrm{NaNO}_{3}\right)$. The basal medium 
was shaken with speed $150 \mathrm{rpm}$ at temperature $55^{\circ} \mathrm{C}$ for 24 hours. $10 \%$ of culturing was moved into a new basal medium and then shacked with agitation speed $150 \mathrm{rpm}$ for 24 hours. The culturing bacteria was centrifuged with speed 5.000 rpm for 5 minutes. The supernatant that produced was moved into a new microcentrifuge tube for bacteria amylase assay.

\section{Bacteria amylase assay}

$0.5 \mathrm{ml}$ substrate $1.5 \%(\mathrm{w} / \mathrm{v})$ in buffer potassium phosphate $\mathrm{pH} 8.0$ was incubated at temperature $55^{\circ} \mathrm{C}$ for 5 minutes, then added $0.5 \mathrm{ml}$ bacteria amylase and incubated for 1 hour at temperature $55^{\circ} \mathrm{C}$. Substrate-bacteria amylase solution was heated with boiling water for 20 minutes and then added $1 \mathrm{ml}$ Samogy-Nelson solution then heated with boiling water for 20 minutes (Nelson, 1944). Tha solution was cooled using running water for 1 minute and added $1 \mathrm{ml}$ Arsenomolibdat solution and then was vortexed and the absorbance was measured at wavelength 540 nm using a spectrophotometer.

\section{Results and Discussion}

Bacillus licheniformis strain SEM11 has been successfully isolated from the Semurup hot spring. Many micro-organisms especially several species belonging to Bacillus are known to produce a variety of extracellular enzymes and they have a wide range of industries applications (Annamalai et al., 2011). Optimization of bacteria amylase activity and production medium is done through optimization of substrates, substrates concentration, temperature, $\mathrm{pH}$, nutrition factor, especially carbon and nitrogen sources.

The use of various substrates such as rice, wheat, potato, and sago was done to determine the optimum activity of amylase from Bacillus licheniformis strain SEM11 (Figure 1). The highest amylase activity was obtained by using rice as a substrate when compared to wheat, potatoes, and sago. This is caused the nutritional content of each starch is different. According to Simanjuntak (2006), the nutritional composition of rice consists of carbohydrates $767 \mathrm{~g}, 75 \mathrm{~g}$ protein, $18 \mathrm{~g}$ of fat, $130 \mathrm{~g}$ of water, $14 \mathrm{mg} \mathrm{Fe}, 150 \mathrm{mg} \mathrm{Ca}, 3.30$ $\mathrm{mg}$ thiamine, $46 \mathrm{mg}$ niacin and $4.5 \mathrm{mg}$ riboflavin. The nutritional composition of wheat, potatoes, and sago has nutrients smaller than rice. Optimum activity of bacteria amylase from Bacillus tequilensis RG-01 was obtained by wheat (Tiwari et al., 2014). In contrast to Bacillus licheniformis optimum activity of bacteria amylase obtained by using starch as a substrate (Divakaran et $a l ., 2011)$. Rice, wheat, sago, and potato were the natural substrate that can be used to produce bacteria amylase so as to reduce production costs.

Effect of substrates concentration in Figure 2 shows the bacteria amylase optimum activity was at rice substrate concentration $1.5 \%$. Above and below the concentration bacteria amylase activity decreased. The same results on the amylase optimum activity of Bacillus sp SMIA-2 strain with $1.5 \%$ substrate concentration (Carvalho et al., 2008). Different from Bacillus cereus strain BRSCS-A26MB, bacteria amylase optimum activity was obtained at substrate concentration $0.5 \%$. The increase of substrates concentration did not affect the increase of enzyme activity (Halder et al., 2014). The mechanism of action of the enzyme is determined by the available substrate concentration.

If the substrate concentration is low, the enzyme's working speed is also low. Conversely, if substrate concentrations are available a lot, enzyme work is also fast. In the state of the excess substrate, enzyme work is not decreased but constant. 


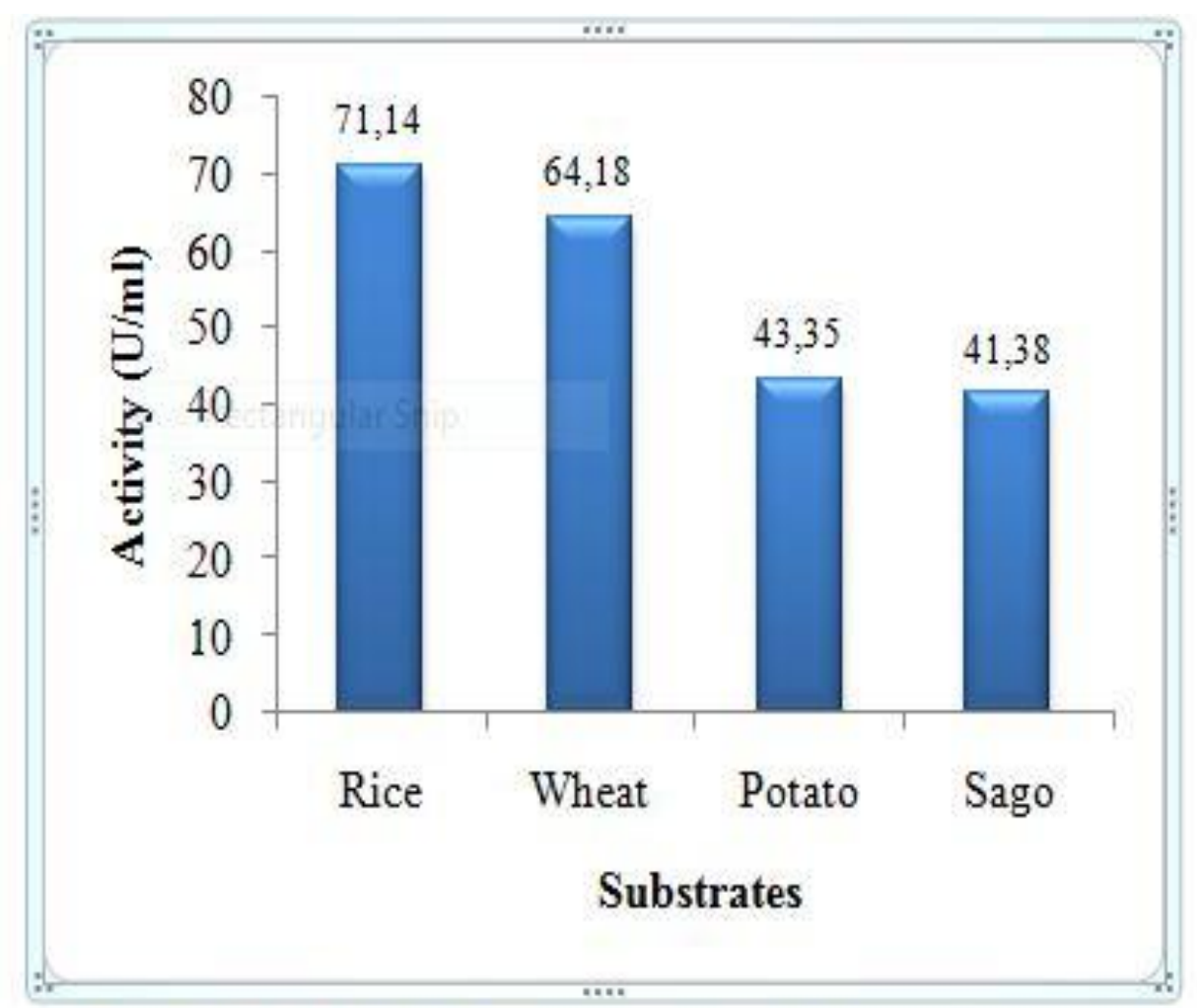

Figure 1. The effect of substrates on bacteria amylase activity

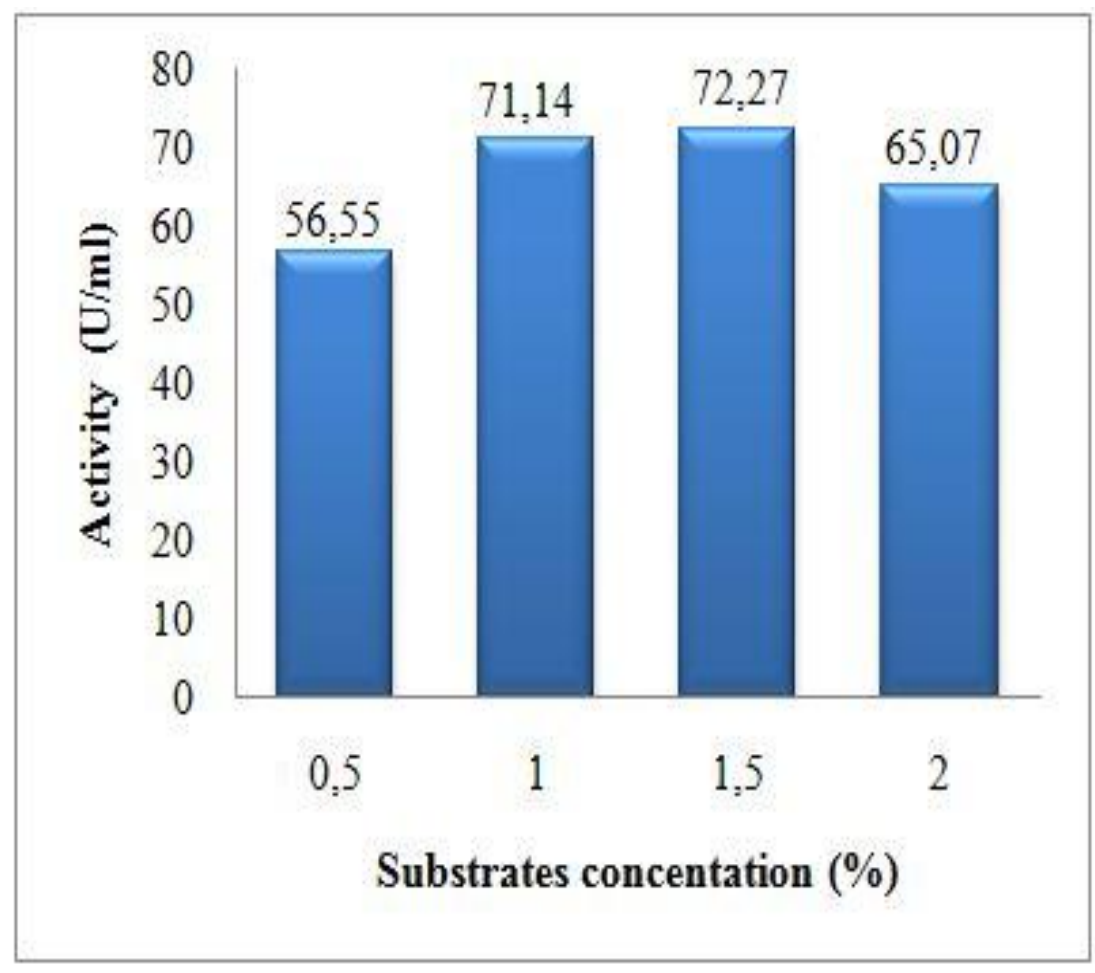

Figure 2 . The effect of substrates concentration on bacteria amylase activity 


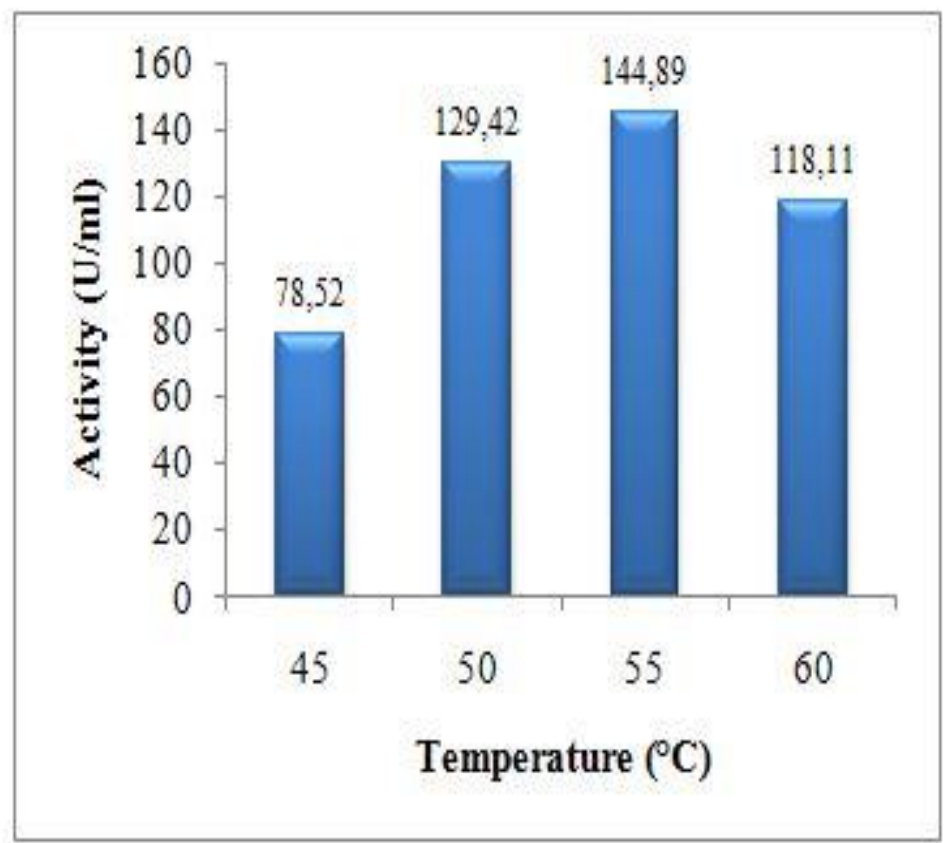

Figure 3. The effect of temperature concentration on bacteria amylase activity

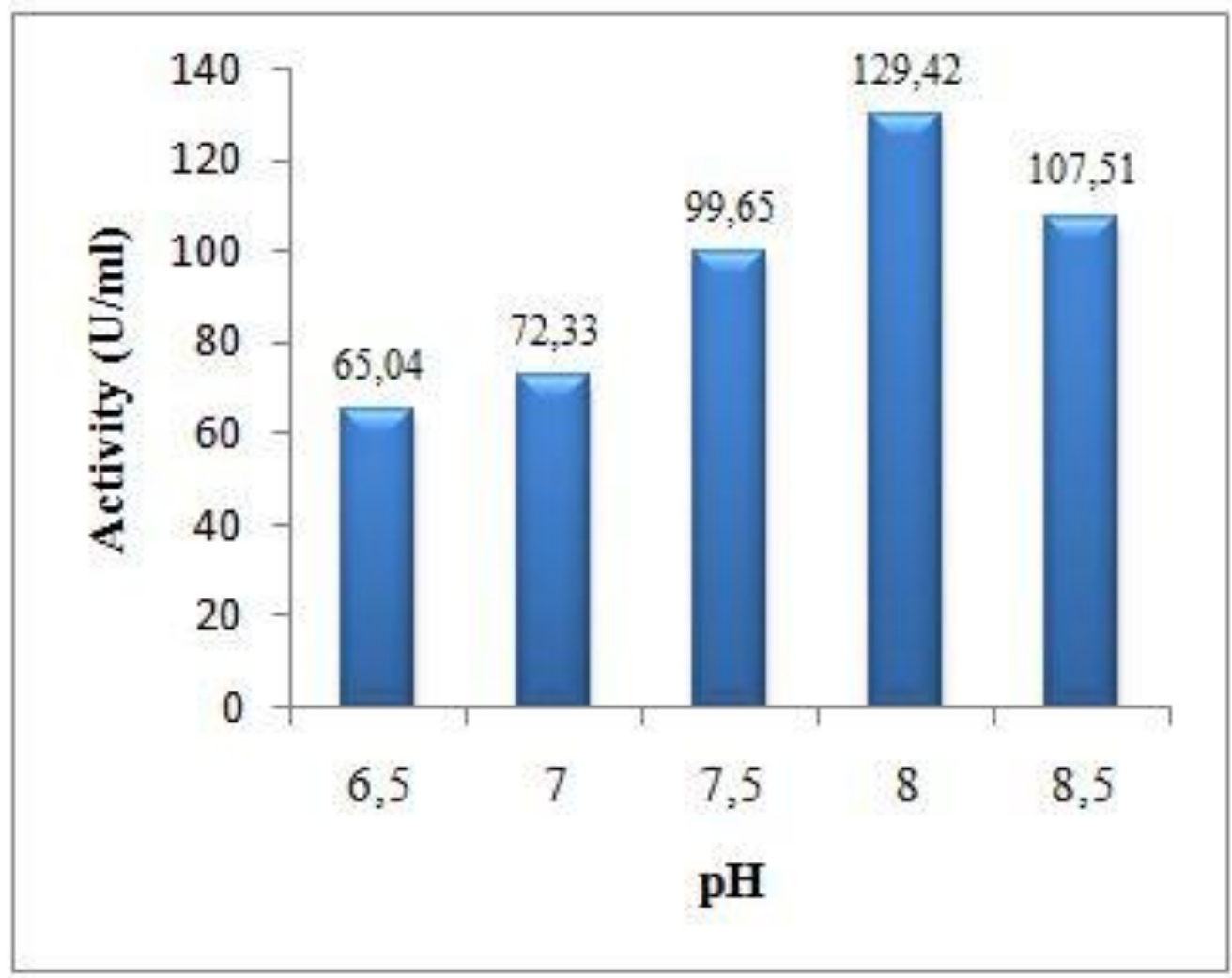

Figure 4 . The effect of $\mathrm{pH}$ on bacteria amylase activity 


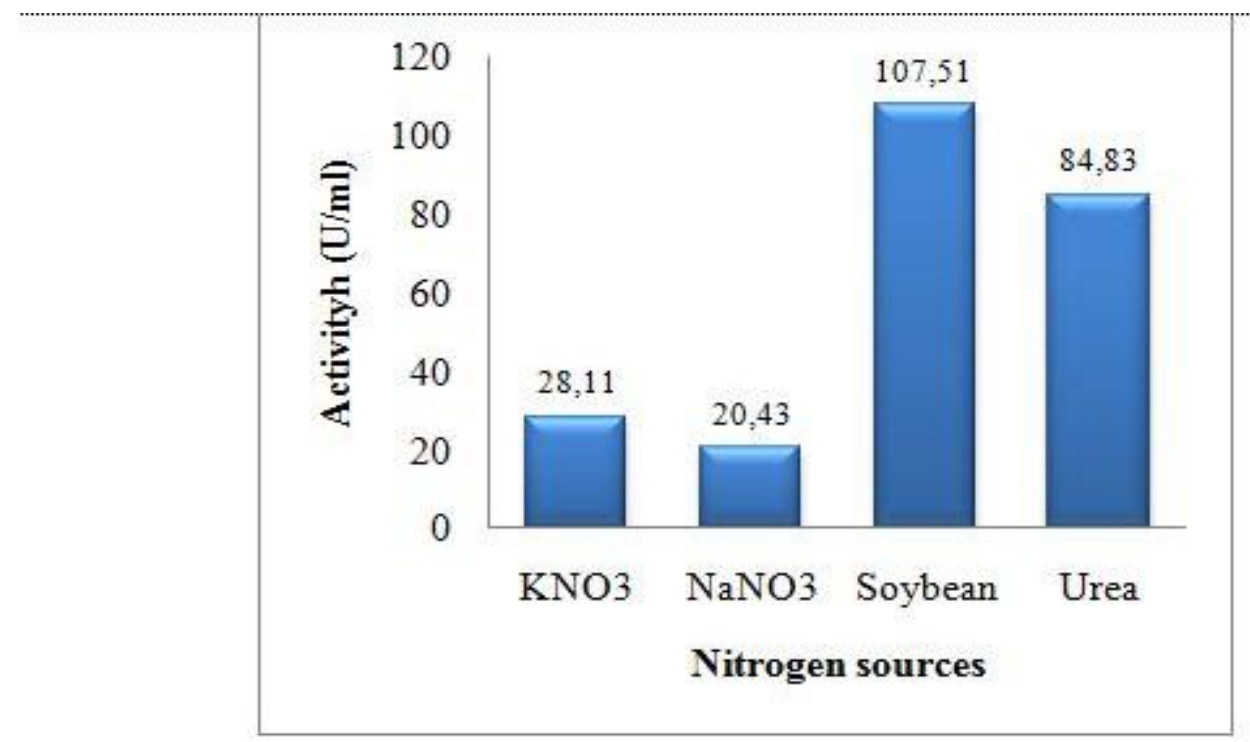

Figure 5 . The effect of nitrogen sources on bacteria amylase activity

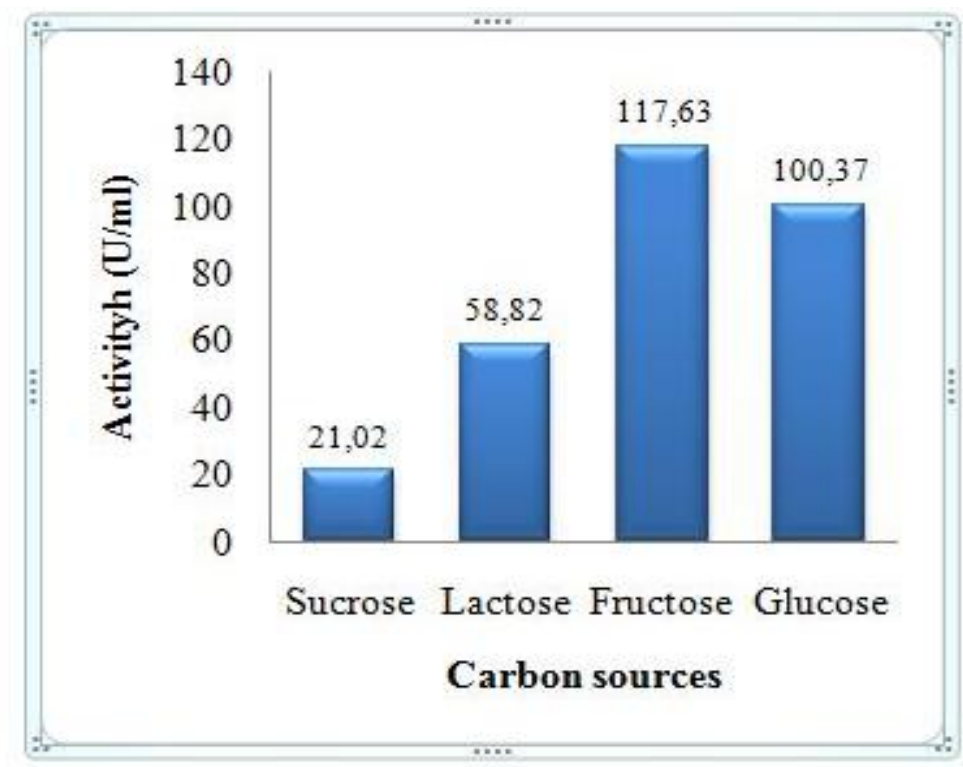

Figure 6 . The effect of carbon sources on bacteria amylase activity

The optimum temperature of amylase activity was obtained at $55{ }^{\circ} \mathrm{C}$ and at $60{ }^{\circ} \mathrm{C}$ the activity of amylase decreased (Figure 3 ). The increased temperature did not affect the activity of amylase from Bacillus licheniformis strain SEM11. Similar studies reported optimum amylase activity of Bacillus sp WA21 at $55{ }^{\circ} \mathrm{C}$ (Asad et al., 2011). Likewise with the optimum activity of amylase from Bacillus strearothermophilus at
$55{ }^{\circ} \mathrm{C}$ (Cakraborty et al., 2000). Similar studies reported optimum amylase activity of Bacillus sp WA21 at $55{ }^{\circ} \mathrm{C}$ (Asad et al., 2011). Likewise with the optimum activity of amylase from Bacillus strearothermophilus at $55^{\circ} \mathrm{C}$ (Cakraborty et al., 2000). The decrease in the enzymatic rate will decrease at high temperatures this is due to the enzyme denaturation resulting in conformation changes at too high temperatures so that the 
substrate is inhibited in entering the active side of the enzyme. While at very low incubation temperature can result in the small amount of kinetic energy produced so that it can decrease the intensity between enzyme and substrate.

The optimum activity of amylase from Bacillus licheniformis SEM11 strain was obtained at $\mathrm{pH} 8,0$ while at $\mathrm{pH} 8,5$ decreased amylase activity (Figure 4). This means that the amylase produced by Bacillus licheniformis SEM11 strain can be used commercially in various industries because it is thermostable $\left(55^{\circ} \mathrm{C}\right)$ and alkaline ( $\left.\mathrm{pH} 8.0\right)$. The thermostable and alkaline amylases are also produced by Bacillus cereus with a temperature of $65^{\circ} \mathrm{C}$ and $\mathrm{pH} 8.0$ (Annamalai et al., 2011). In contrast to SS1, SS2, and SS3 isolates having an optimum $\mathrm{pH}$ of amylase activity at pH 7.0 (Kumar et al., 2012). pH affects the velocity of enzyme activity in catalyzing a reaction. Each enzyme has an optimum $\mathrm{pH}$ wherein the $\mathrm{pH}$ is threedimensional structure most conducive to binding to the substrate. Likewise, according to Lehninger (2005), pH greatly affects enzymatic reactions where $\mathrm{pH}$ changes directly affect enzyme ionic groups, thus affecting enzyme activity and enzyme conformation. In addition, the $\mathrm{pH}$ change is too large above the optimum $\mathrm{pH}$ to cause enzyme denaturation. Winarno, 1995 states that the enzyme exhibits maximum activity in a range called optimum $\mathrm{pH}$ which is generally between $\mathrm{pH}$ 4.5-8.

Sources of nitrogen and carbon added to the basal medium can increase or decrease the activity and production of bacteria amylase. Nitrogen source of soybean can increase the activity and production of bacteria amylase compared with urea, KNO3, and $\mathrm{NaNO}_{3}$ (Figure 5). In accordance with the results of research Francois et al., (2014), bacteria amylase activity is increased by using soybean as a source of nitrogen. Soybean flour is a good source of organic nitrogen used for the production of bacteria amylase and cheaper so it can save production costs than inorganic nitrogen sources. In contrast to Halder et al., (2014), Casein is the best source of nitrogen in the production of bacteria amylase. Nitrogen source served as a secondary energy source for growth and enzyme secretion (Kumar et al., 2012).

The carbon source (fructose) can increase the activity and production of bacterial amylase compared to other carbon sources (Figure 6). Fructose was the most effective in stimulation and growth of bacteria May and Chen, (1997) for this amylase formation and Ashraf et al., (2005). In contrast to research Nwagu and Okolo, (2011); Sreekant et al., (2013) glucose is a good source of carbon in increasing the activity and production of bacteria amylase. In contrast to Sudharhsan et al., (2007), lactose can increase the activity and production of bacteria amylase compared to glucose, fructose, and sucrose. Molasses was found to be the best carbon source for microbial growth and amylase fermentation. This occurred probably due to the presence of growth promoters and other nutrients in molasses (Simair et al., 2017). Carbon sources have two important roles as raw materials for the structure and act as an energy source (Hasan and Hameed, 2001).

\section{Acknowledgement}

The authors thank the Directorate of high education (DIKTI) which has given funding this research to Head of microbiology and genetics laboratory of Andalas University as well as head of microbiology laboratory of Padang State University.

\section{References}

Annamalai NR, Thavasi S, Vijayalaksmi and Balasubramanian T (2011). Extraction, purification and characterization of 
thermostable, alkaline tolerant $\alpha$ amylase from Bacillus cereus. Indian Journal of Microbiol 5(14):424-429.

Anto HU, Trivedi and Patel K (2006). Alphaamylase production by Bacillus cereus MTCC 1305 using solid-state fermentation. Food Technol Biotechnol 44:241-245.

Asad W, Asif M and Rasool A (2011). Extracelullar enzyme production by indigenous thermophilic bacteria of $\alpha$ amylase by Bacillus SP.WA21. Pakistan Journal Botany 43(2):1045-1052.

Ashraf HK, Rana H Zainab and Ul-hag I (2005). Production of alpha-amylase by a thermophilic strain of Bacillus licheneformis. Journal of Food Technology 3(1):64-67.

Babu RS, Sankar R Balasubramanian and Jayalakshmi S (2014) Amylase production

Bacillus circulans ATCC 4516 with solid state fermentation. J. Biol. \& Chem. 40 (4):393-400.

Cakraborty K, Bhattarcharyya BK and Sen SK (2000). Purification and characterization of a thermostable $\alpha$ amylase from Bacillus stearotherophilul. Folia Microbial (Praha) 45(3): 207-210.

Carvalho RV, Correa TRM, Silva JCM, Mansur LRC and Martin MLM (2008). Properties of an amylase from thermophilic Bacillus sp. Brazilian Journal of Microbiology 39:102-107.

Dash BK, Rahman MM and Sarker PK (2015). Molecular identification of a newly isolated Bacillus subtilis BI19 and optimization of production conditions for enhanced production of extracellular amylase. BioMed Research International 2014:1-9.

Divakaran D, Chandran A and Chandran P R. (2011). Comparative study on production of a-amylase from Bacillus licheniformis. Brazilian Journal of
Microbiology 42: 1397-1404.

Djekrif D, Gillmann S, Chochet LN, Bennamoun L, Ait-kaki, Labbani L, Nouadri T and Meraihi Z. (2014). Optimization of thermophilic pullulanase and a-amylase production by amylolytic yeast. International Journal of Microbiology Research 6(Issue 2):559-569.

Francois N, Niyonzima, Sunil S and More. (2014). Concomitant production of detergent compatible enzymes by Bacillus flexus XJU-1. Brazilian Journal of Microbiology 45(3): 903910.

Halder D, Biswas E and Basu M. (2014). Amylase production by Bacillus cereus strain BRSC-S-A26MB. International Journal of Current Microbiology and Applied Sciences 3(6): 1035-1047.

Hasan F and Hameed A. (2001). Optimization of lipase production from Bacillus sp. Pak. J. Bot 33:789-796.

Ibrahim D, Yosuf HLN Isnaeni and Hong LS. (2013). Bacillus licheniformis BT5.9 isolated from changar hot spring, Malang, Indonesia, as a potential producer of thermostable $\alpha$-amylase. Tropical Life Sciences Research 24:7184.

Kalaiarasi K and Parvatham R. (2013). Optimization of process parameters for $\alpha$-amylase production under solid-state fermentation by Bacillus cereus MTCC 1020. African Journal of Microbiology Research 7(45):5166-5177.

Khusro A, Barathikannan K, Aarti C and Agastian P. (2017). Optimization of thermo-alkali stable amylase production and biomass yield from Bacillus sp. under submerged cultivation. Fermentation 3(7) doi: 10.3390.

Kumar AP, Kumar KJ and Narasimha G. (2012). Isolation of lipase-producing fungi from groundnut oil mill effluent soil site at Nandyal. Int. J. Pharm Bio 
Sc. 3:275-280.

Lehninger, A. L., Nelson, D. L. and Cox, M. M. 2005. Principles of biochemistry.

Mei JS and Chen YH (1997). Studies of the different nutrient source of alphaamylase fermentation by Bacillus amyloliquefaciena. J. Chem. Eng 28:18.

Nelson N. (1944). A photometric adaptation of the Samogyi method for the determination of glucose. Journal of Biological Chemistry. 153(2):375-380.

Nwagu TN and Okolo. (2011). Extracellular amylase production of a thermotolerant Fusarium sp. isolated from Eastern Nigerian soil. Brazilian Archives of Biology and Technology. 54(4):649658.

Remigio Z, William M, Olle $\mathrm{H}$ and Wilson $\mathrm{P}$. (2012). Isolation and characterization of a protease-producing thermophilic bacterium from African hot spring. African Journal of Biotechnology 11(62):12571-12578.

Serin B, Akcan N and Uyar F. (2014). Production and optimization of aamylase from marine bacteria Micrococcus roseus associated with Polychaetes. Journal of Sciences 4(11):686-691.

Simair AA, Qureshi, AS, Khushk I, Ali CH, Lashari, Bhutto MA, Mangrio GS and Lu C. (2017). Production and Partial Characterization of $\alpha$-Amylase Enzyme from Bacillus sp. BCC 01-50 and Potential Applications. BioMed Research International. 9 pages https://doi.org/10.1155/2017/9173040
Simanjuntak D. (2006). Pemanfaatan komoditas non beras diversifikasi pangan sumber kalori. Jurnal Penelitian Bidang Ilmu Pertanian 4(1): 45-54.

Souza PM and Magalhaes PO. (2010). Application of microbial $\alpha$-amylase in industry-a review. Brazilian Journal of Microbiology 41:850-861.

Sreekanth MS, Vijayendra SVV, Joshi GJ and Shamala TR. (2013). Effect of carbon and nitrogen sources on simultaneous production of $\alpha$-amylase and green food packaging polymer by Bacillus sp. CFR 67. Journal Food Sci Technol. 50:404408.

Sudarhsan S, Senthilkumar S and Ranjith K. (2007). Physical and nutritional factors affecting the production of amylase from species of Bacillus isolated from spoiled food waste. African Journal of Biotechnology 6(4):430-435.

Suribabu K and Hemalatha KPJ. (2016). Thermal optimization of $\alpha$-amylase production in Brevibacillus sp. International Journal of Current Microbiology and Applied Science 5(3):909-916.

Tiwari S, Shukla N, Mishra P and Gaur R. (2014). Enhanced production and characterization of a solvent stable amylase from solvent tolerant Bacillus tequilensis RG-01: thermostable and surfactant resistant. The Scientific Wolrd Journal 11:1-11.

Winarno, F.G. 1995. Biokimia Pangan. Gramedia Utama, Jakarta. Pp 46-47.

\section{How to cite this article:}

Ruth Rize Paas Megahati, Mansyurdin, Anthoni Agustien and Djong Hon Tjong. 2017. Optimization of Bacteria Amylase Activity from Bacillus licheniformis Strain SEM11. Int.J.Curr.Microbiol.App.Sci. 6(11): 2938-2946. doi: https://doi.org/10.20546/ijcmas.2017.611.345 